\title{
A Compilation of Web Resources for Educators
}

\author{
Linda Knight and Theresa Steinbach \\ DePaul University, Chicago, IL, USA
}

\author{
Iknight@cdm.depaul.edu; tsteinbach@cdm.depaul.edu
}

\begin{abstract}
In this assemblage of Web resources for educators, we identify specific sites that provide high quality, free services of interest to teaching professionals. These resources will be of particular interest to schools whose budgets are strained or whose faculty or students are working with limited funds. While there is a wealth of resources available on the Web, faculty have had little guidance in terms of weeding through the contenders to identify those no-charge resources that are of ample quality. In this manuscript, we identify blog hosts, wiki hosts, social networking site hosts, and website hosts that we have found suitable for educational use. We also identify excellent sources for free website templates and HTML/CSS editor software. In the process of describing these resources, we simultaneously identify key criteria to consider when making a selection in each of the categories we discuss. We do not duplicate the rich existing literature on the educational use of these resources, but rather add information on specific effective software and services available without charge.
\end{abstract}

\section{Introduction}

This paper is intended to provide teachers of all subjects and levels with a guide to the abundant Web resources that are available at no cost. A rich literature already exists identifying how websites, blogs, wikis, social networks, and the like might be used in teaching and learning. Our goal is not to replicate that literature. Rather, our goal is to document effective, quality free resources available to faculty members. In the process, we also identify the major criteria for selecting a resource to implement. We cover four major areas, from the simplest to use to the most technically complex: Blogs, Wikis, Social Networks, and website creation using templates or HTML.

If this guide is to be of any practical use, then we must mention specific Web resources by name. We believe, based upon our own experience in trying and eliminating many other sites, that the sites mentioned here are worthy of consideration. That said, there are almost certainly are other equally high quality sites available. We could not possibly be exhaustive in our list. However, we do encourage other faculty, who have successfully used similar resources to recommend them to us so that our work might be continually updated.

Material published as part of this publication, either on-line or in print, is copyrighted by the Informing Science Institute. Permission to make digital or paper copy of part or all of these works for personal or classroom use is granted without fee provided that the copies are not made or distributed for profit or commercial advantage AND that copies 1) bear this notice in full and 2) give the full citation on the first page. It is permissible to abstract these works so long as credit is given. To copy in all other cases or to republish or to post on a server or to redistribute to lists requires specific permission and payment of a fee. Contact Publisher@InformingScience.org to request redistribution permission.

\section{Blogs}

A blog is a Web log, typically a website maintained as a running commentary by one individual. Most blogs are either online diaries or focus on a particular subject of interest to the blogger and the blog's readers. Some focus on art, photography, music, or video, but many are text-centric. Blogs can be private or 
public, and have become so popular that Wikipedia even maintains a list of notable blogs at http://en.wikipedia.org/wiki/List of blogs. An easy method of automatically alerting readers when a blog has been updated is to use a site feed. A site feed such as a Rich Site Summary (RSS) feed is a machine-readable representation of a blog that users can subscribe to and then read using Feed Reader software (Lee et. al., 2009). This technology can reduce the complexity of receiving and organizing content, enabling participants to attend to more pertinent tasks such as self-assessment, critical reflection and the provision of feedback to others. RSS readers are available for multiple platforms and a ranking of the most popular readers can be found at http://blogspace.com/rss/readers. Most commercially-hosted blogs can easily add an RSS feed.

\section{Potential Uses of Blogs in Academia}

Blogs can be either a way of communicating information or a source of information. Blogging can enable the sharing of ideas and interaction (McLoughlin \& Lee, 2007). Blogs can be used by faculty in any subject area to maintain a single source for all course related postings. Faculty in language or communication subjects can use student blogs as a way to encourage students to practice and refine writing skills. Armstrong and Lamshed (2007) found that since students' postings are not anonymous and published, they are more careful in the choice of words which they use and how their thoughts are represented, resulting in an improvement in their English literacy. When studying contemporary society or politics, blogs can be particularly useful sources of current opinion about an event or topic of contemporary interest, as long as readers are aware that users are likely to be younger and more technologically adept than the population as a whole. Blogs can provide an opportunity for students to be aware of different perspectives. Using blogs can also provide a lead into classroom consideration of evaluating Web resources for their accuracy and currency. Kirk and Johnson (2009) identified three possible approaches based on the focus of the blog. Instructor-focused is a push of information from the instructor to the students. Learner-focused allows communication between instructor and students as well as between students. An interactive community-focused approach can create a virtual learning environment. Six distinct "classroom blogging practices" have been identified: (a) sharing resources; (b) responding to teacher prompts; (c) recording lessons' highlights; (c) posting learning challenges; (e) reflecting on what was learned; and (f) engaging in on-line conversations (Luehmann \& MacBride. 2009). Whenever blogs are used, not as a way of sharing information, but as a source of information, blog search engines are valuable.

\section{Blog Search Engines}

Blog search engines can be used to identify either blogs or blog entries on a particular topic of interest. Some common blog search engines are listed alphabetically in Table 1. Note that some of these include only certain types blogs while others set no standards for what they return. Others emphasize top stories of immediate interest or let you create your own blog portal. 
Table 1. Common blog search engines, in alphabetical order

\begin{tabular}{|c|c|c|}
\hline Blog search engine & url & Notes \\
\hline Best of Blog & http://www.bestofblog.com/ & $\begin{array}{l}\text { "...human powered to only } \\
\text { provide results from the top } \\
\text { bloggers and blogs in the blo- } \\
\text { gosphere." }\end{array}$ \\
\hline Best of the Web Blogs & http://blogs.botw.org/ & $\begin{array}{l}\text { Only covers blogs that meet } \\
\text { their standards. Includes abil- } \\
\text { ity to search by category, as } \\
\text { well as by search words. }\end{array}$ \\
\hline Blog Catalog & http://www.blogcatalog.com/ & $\begin{array}{l}\text { Young look. Emphasis on } \\
\text { community. }\end{array}$ \\
\hline Blog Pulse & http://www.blogpulse.com/ & $\begin{array}{l}\text { Opening page shows where } \\
\text { the action is in blogging at the } \\
\text { moment. }\end{array}$ \\
\hline Bloglines & http://www.bloglines.com/ & $\begin{array}{l}\text { Also lets you create and per- } \\
\text { sonalize your own portal into } \\
\text { the blogosphere. }\end{array}$ \\
\hline Blogscope & http://www.blogscope.net/ & $\begin{array}{l}\text { Lets you view search results } \\
\text { based on combinations of } \\
\text { recency, relevance, and influ- } \\
\text { ence. }\end{array}$ \\
\hline Google's Blog Search & http://blogsearch.google.com/ & $\begin{array}{l}\text { Lets you ask for top stories on } \\
\text { various topics from video } \\
\text { games to politics. }\end{array}$ \\
\hline Techorati & http://technorati.com/ & $\begin{array}{l}\text { Lets you search for either } \\
\text { blogs or posts about your } \\
\text { topic. }\end{array}$ \\
\hline
\end{tabular}

\section{Creating a Blog}

Blogs can be easily created at no cost. Two sites that make it easy to quickly create your own blog are Wordpress and Blogger, which is a portion of Google. Blogger asks you to sign in using a gmail account and then lets you select a name and template for your blog. Your selected blog name is a subdomain within http://www.blogger.com. You can designate your blog as a team blog, which allows multiple users to post on the same site. Wordpress operates similarly to Blogger. Commentpress, an open source theme and plugin for the WordPress blogging engine (http://www.futureofthebook.org/commentpress ), allows readers to comment paragraph by paragraph in the margins of a text. It can also turn a document into a conversation. However, in terms of ease of use for the less technical, we believe Blogger has the edge. There are those who might find tying their blog to their gmail account (which may be tied to other personal data) to be either invasive or at least a risk to their privacy. This is a decision each individual must make. The only substantial downside to using either Wordpress or Blogger is that if your chosen organization stopped supporting your blog, its contents might be lost forever. This is a potential problem when depending on any webhost. Once you have determined to be a continual blogger, you may choose to sign up for a domain name for your blog. If you do this, you would not be forced 
to be a subdomain under an organization like Wordpress or Blogger, and you would have the ability to move your blog to other webhosts while keeping the same url. For more information on webhosts, see the section on Creating websites, below.

\section{Wikis}

Where blogs typically reflect the work of one individual, Wikis are community websites, set up to allow multiple users to work together collaboratively adding and editing content. Beyond collaborative editing, a good wiki should provide an audit trail or history of changes. Some wikis are open to the public, while others are private.

\section{Potential Uses of Wikis in Academia}

Wikis can be used either for in-depth collaborative work, where multiple users are editing the same document, or for short back-and-forth commentary. Because of their collaborative nature, they lend themselves to having students mentor one another's writing. Wikis can more thoroughly integrate the roles of author and reader (Lundin, 2008). Wikis also provide a way to allow students to design a project collaboratively. Student work groups can use wikis as a simple way of communicating that, unlike email, provides a permanent record of comments and plans. Faculty members may appreciate the open way in which wikis show the contributions of each member of a student group. For a wiki to function as a learning space, it may be necessary for faculty to encourage students "to edit, amend and challenge each other via the direct manipulation of each other's text" (Hemmi et. al., 2009). An analysis by Aharony (2008) of a wiki, used in a knowledge management course, indicates students actively participated in the discussion section of the wiki but were not comfortable in editing or amending documents. Cummings and Barton (2008) have categorized wikis into five classifications: resource, presentation, gateway, simulation and illuminated. The two most popular uses in the classroom are the resource and presentation wikis. A resource wiki is the assemblage of a collaborative knowledge base (p. 21) and a presentation wiki has an internal focus for the convenience of the class, peer evaluation and as a communication forum (p. 23).

\section{Creating a Wiki}

Free Wiki creation and hosting is available at numerous sites, including Wikia (http://www.wikia.com/Wikia) and PBworks (http://pbworks.com/). Wikia is a large community of communities featuring many social and celebrity topics and has plentiful advertising on its site. It has a young, hip image, while PBWorks has a more professional representation and appears aimed at enrolling paid users, either from businesses, organizations, or schools. PBWorks allows free individual or individual classroom use. With PBworks, both logos and backups require upgrading to a paid account, although their annual costs are still under $\$ 100$ for a single course. As a free user, both sites allow you to create /download your own backup zip files, but uploaded image or document files are not included in the backups. This serious disadvantage for educational users, could be overcome by keeping your own backup folder of posted files. You would still need to download your site's most current backup of postings as a zip file. Neither site is really designed for posting documents, although this appears easier on PBWorks. Wikia will let you upload pdfs as images. PBWorks allows you to limit viewing of your site to members, while Wikia offers the ability to 'protect' pages. Overall, for educators, we recommend PBWorks over Wikia for its clean, professional interface and ease of use. If creating and using a Wiki is part of a student assignment and motivation is a consideration, then we would consider WetPaint (which we list under 'social networking' sites), and which has a younger, more hip image, but allows much of the same functionality. 
A secure online workspace is easily created on PBWorks by providing a name for the Wiki, which becomes part of the URL, an email address and a password. During the initial setup, access can be given to students and other interested parties such as faculty collaborators. Control is provided through a unique login and password which provides an audit trail for workspace edits and notification of changes to the workspace is sent via email. Multiple workspace-wide access levels (Reader, Writer, Editor, and Administrator) can be assigned. PBworks can be seamlessly integrated with online learning tools from Blackboard and Wimba to improve the online learning experience and increase the interaction between students and faculty. After an account is created, a WYSIWYG editor that has the look-and-feel of a Windows application is used to edit the pages. Nine color templates are available with the free account. Common headings, e.g. assignments and syllabus, and plug-ins, e.g. calendar and YouTube videos, are integrated in the editor. HTML and JavaScript are easily incorporated. You can allow users to access the workspace's RSS feed. A Web Hook, a method to send events to another server or Web service based on actions performed by users on this workspace, can be enabled. Best Practices in site design and sample assessment rubrics are available to guide the educator. Instructional videos, a user manual and a PBworks educator community offer additional support.

\section{Social Networking Sites}

In social networks, including the popular Facebook (htttp://www.facebook.com), individuals create their own profiles and then allow access to friends or individuals with similar interests. The initial opening point of such networks is thus often the individual and his or her profile. Alternatively, organizations can set up a presence on a social network for their individual followers to access, making the entry point in this example the group site.

\section{Potential Uses of Social Networks in Academia}

In the classroom, social networking sites can aggregate information from a variety of Web 2.0 tools, providing a platform to synthesize and distribute the information by focus areas. Students also benefit from participating in the learning community and become life-long learners. The use of these sites can transition students to the work place as professionals who are comfortable in organizations that depend on a virtual professional culture and better integrate in an environment of cross-cultural employees (Agarwal \& Mital 2009). Panckhurst (2009) suggests that a social network can allow students to "take up the 'independence' challenge and direct their own learning." As students have become more familiar with the technology of social networks, their novelty has worn off. The success of these networks in learning environments now depends on the social networks having a clear purpose, a structure that is supportive of that purpose, and integration with other course resources.

For university level faculty, social networking sites can assist with research agendas by supporting an internal reference group, providing cross-collaboration opportunities, and prospects for professional development. At the eResearch Australasia conference in 2009, the Australian Research Collaboration Server (ARCS) held a Birds of a Feather discussion on investigating a number of Web based collaboration tools which can be used to help facilitate collaborative research. Numerous research collaboration search tools such as ReMarkables exist but do not include the technologies and features associated with social networks.

\section{Creating a Social Network}

Ning (http://www.ning.com) and WetPaint (http://www.wetpaint.com), are two sites that allow anyone, including educators, to take the organizational role in setting up a group networking site for a community of shared interests. Both sites are relatively easy to use and to navigate. In both cases, the emphasis is upon facilitating discussion, not upon posting existing documents or im- 
ages. These can be added by attaching them to a discussion posting. Both sites allow group members to set up and maintain their own profiles and pages. The sites differ in two major areas that may be of interest to academics. First, while Ning allows you to limit viewing of the site to members, WetPaint does not. Second, both sites allow you to create your own zip file backups. However, perhaps because the sites have their roots in wikis, where the emphasis is on the shared conversation or editing of text, the backups do not include posts of image or document files. Ning has an advantage here in that it posted the following on one of its forums: "We regularly back up all content on the platform. As such, we can provide a recent version of your network if it is accidentally deleted. We are also happy to do a one-time export of all content, if you are looking to leave the platform" (http://creators.ning.com/forum/topics/backing-upcontent?commentId=4244211\%3AComment $\% 3 \mathrm{~A} 81920 \& \mathrm{xg}$ source=activity).

\section{Website Creation}

Website creation involves two major functions: first, building the website itself and then identifying and uploading the site to a host server. We address free, high quality resources for each of these functions in turn.

\section{Website Building}

\section{Website building in academia}

Website creation has two major purposes in academia. Obviously, Information Technology faculty may want to teach students to build websites. Beyond this, faculty in any subject area may wish to create their own Website to house course related materials. There are two major ways to create a website, through coding, typically HTML, likely with CSS or other technologies, and through the use of a template. Links to numerous sites offering the download of free HTML templates are readily available through any search engine. Among the sites providing free templates are http://www.freelayouts.com, which includes blog and myspace layouts as well as general webpage layouts, http://www.2createawebsite.com/build/templates.html, which includes some very simple site designs, and http://www.templatesbox.com, which categorizes templates by the site purpose for easier searching. These templates offer the bones of a professional looking website without the content. In order to put your content on the Web, you still need a program to edit that HTML code to make it your own. Some webhosts provide these online. Others do not. We next consider options for editing a website in HTML on your own computer.

\section{Creating a website}

While Notepad or any traditional text editor will allow saving an html file, coding a webpage is facilitated by using an editor designed for that purpose. We recommend two here. Alleycode (http://www.alleycode.com) offers a free html editor with full support for HTML, XHTML, CSS, and PHP. Text entered is color coded to aid in debugging, although we do find the fact that green indicates an error is somewhat counterintuitive. Alleycode allows interactively flipping to a browser to view the page you are editing, or opening a window within Alleycode for a synchronized view. Alleycode includes the ability to work on multiple pages at one time and a 'color picker' function that will insert the appropriate hexadecimal value for a color selected. It also includes ftp access within the program for uploading Web files to a server, as well as a built-in HTML/CSS tutorial. Where Alleycode is available only for PCs, Komodo Edit is available in both a Mac and a PC version at http://download.cnet.com. Unlike Komodo IDE, which is a paid product, Komodo Edit is based on the Mozilla code base and licensed as free to use under the same terms as Firefox. While somewhat more complex to use than Alleycode, it offers more features. 


\section{Website Hosting}

For a website to be accessible on the World Wide Web, it must be hosted on a server. A server is typically a larger computer specifically set up to house websites. While some organizations, typically those that are larger, host their own sites, professional webhosting companies host websites for organizations from very small to mammoth in size. Many of these professional webhosts offer free site hosting. In addition to faculty use, this free hosting can be an alternative for course use in universities that do not host student websites, or for students who want a dependable host that will continue to house their site after graduation.

\section{Free Webhosting services}

Our preference, in terms of free hosting services, goes to those organizations that do not place advertisements on the free hosted sites. These services typically offer the free hosting to give a sample of their services, in the hope that the hosted sites someday will grow into paid sites, or that those who have a positive individual experience with the host company will encourage current or future employers to consider the host's paid services. We find all of the following professional hosting services provide exceptional free services: www.110mb.com, www.50webs.com, www.atspace.com, and www.byethost.com. None of these sites offer backup services for free accounts, so students and faculty using them are well advised to maintain their own backup procedures. The services do differ in some minor ways from one another, as shown in Tables 2 and 3. Table 2 gives the major technical considerations when selecting a webhost. In addition to the items listed, developers using more sophisticated technologies like background databases, PHP, or ASP will want to make sure they choose a host that supports these technologies.

Table 2. Primary technical considerations when selecting a webhost.

(Table entries reflect attributes of free accounts with these professional hosting services)

\begin{tabular}{|l|l|l|l|l|}
\hline & $\begin{array}{c}\text { Amount of } \\
\text { disk space }\end{array}$ & $\begin{array}{c}\text { Amount of traffic } \\
\text { allowed }\end{array}$ & $\begin{array}{c}\text { Maximum up- } \\
\text { load file size }\end{array}$ & Percent up time \\
\hline $\begin{array}{l}\text { www.110mb.com } \\
\text { Places small 'pow- } \\
\text { ered by' footer on } \\
\text { free sites. }\end{array}$ & $110 \mathrm{MB}$ & $100 \mathrm{~GB}$ monthly & $8 \mathrm{MB}$ & $99 \%$ guarantee \\
\hline $\begin{array}{l}\text { www.50webs.com } \\
\text { No ads of any kind. }\end{array}$ & $60 \mathrm{MB}$ & $\begin{array}{l}\text { Unlimited band- } \\
\text { width. }\end{array}$ & $500 \mathrm{~KB}$ & $99 \%$ \\
\hline$\underline{\text { www.atspace.com }}$ & $50 \mathrm{MB}$ & Unlimited traffic. & $200 \mathrm{~K}$ & Unknown. \\
\hline$\underline{\text { www.byethost.com }}$ & $5500 \mathrm{MB}$ & $200 \mathrm{~GB}$ monthly & $10 \mathrm{MB}$ & Unknown. \\
\hline
\end{tabular}


Table 3. Primary usability considerations when selecting a webhost

(Table entries reflect attributes of free accounts with these professional hosting services).

\begin{tabular}{|l|l|l|l|l|l|}
\hline & $\begin{array}{c}\text { Must set up } \\
\text { your sub- } \\
\text { domain or } \\
\text { virtual host } \\
\text { as a separate } \\
\text { step? }\end{array}$ & $\begin{array}{l}\text { Includes free } \\
\text { templates? }\end{array}$ & $\begin{array}{l}\text { Includes abil- } \\
\text { ity to edit } \\
\text { WYSIWYG } \\
\text { online? }\end{array}$ & $\begin{array}{c}\text { Includes } \\
\text { ability to } \\
\text { edit html } \\
\text { online? }\end{array}$ & $\begin{array}{l}\text { Tech support } \\
\text { for free ac- } \\
\text { counts }\end{array}$ \\
\hline$\underline{\text { www.110mb.com }}$ & NO & YES & YES & NO & $\begin{array}{l}\text { 24/7 forum } \\
\text { and tickets }\end{array}$ \\
\hline$\underline{\text { www.50webs.com }}$ & YES & $\begin{array}{l}\text { Joomla tem- } \\
\text { plates and } \\
\text { Wordpress } \\
\text { themes }\end{array}$ & YES & YES & $\begin{array}{l}\text { 24/7 customer } \\
\text { support; video } \\
\text { tutorials }\end{array}$ \\
\hline$\underline{\text { www.atspace.com }}$ & YES & NO & NO & NO & $\begin{array}{l}\text { Community } \\
\text { forum and } \\
\text { ticket system; } \\
\text { Online docu- } \\
\text { mentation }\end{array}$ \\
\hline$\underline{\text { www.byethost.com }}$ & NO & NO & NO & NO & $\begin{array}{l}\text { Free 24/7 } \\
\text { support; video } \\
\text { tutorials }\end{array}$ \\
\hline
\end{tabular}

There are many other fine hosting services available free or at reasonable cost. For those seeking other alternatives, there are at least three sites that include ratings of webhosts:

http://www.webhostingjury.com/, http://www.vistainter.com/, and http://www.freewebhosts.com/reviews/. Of the sites listed here, in general, we lean toward $110 \mathrm{mb}$ and 50webs, but all those listed have provided excellent service for our students and for us. In addition, http://www.mochahost.com and http://www.afmu.com are notable for their low-cost hosting services for those who wish to acquire their own domain name.

\section{Conclusion}

Whether using a blog, wiki, social network, or website for academic purposes, some key host selection criteria are the same: Is the image of the potential provider consistent with professional academic use? Who is responsible for regular site backups and how are they taken? Can I control access to my site, for example, limiting it to my students? How straightforward is the site to use and to maintain?

For those wishing to collaborate with other faculty about using the web-based features listed here, an excellent resource is Classroom 2.0 (http://www.classroom20.com). Classroom 2.0 is a social networking site for educators interested in integrating Web 2.0 technologies in the classroom.

The site is available in 10 languages. Over 38,000 members have access to over 6,000 discussion forums, over 5,000 blogs, over 450 groups, over 1,700 videos, webinars, workshops and live chat. Most features allow browsing but in order to post, you must become a member. Topics range from iPad in the Classroom to Marzano's instructional strategies to professional development. Members have the ability to create a discussion forum or group if the topic they are interested in is not represented. 
If we have missed an excellent resource in this manuscript, we hope you will share that information with us, and we will endeavor to continually update this work. Site abilities and limitations noted here are as we understand them at the time of writing and may change at any time. Whenever entering into any Web relationship, always check the site for its latest policies and capabilities.

\section{References}

For ease of use, three reference lists are presented. The first list is the traditional one. The second and third lists are annotated lists of Web site references, in alphabetical order and category order, respectively.

\section{Traditional Reference List}

$110 \mathrm{mb}$. (n.d.). Retrieved from www.110mb.com

2 Create a Website. (n.d.). Retrieved from http//www.2createawebsite.com/

50 Webs. (n.d.). Retrieved from http://www.50webs.com

Affordable Multimedia. (n.d.) Retrieved from http//www.afmu.com/

Agarwal, S. \& Mital, M. (2009, March). An exploratory study of Indian university students' use of social networking web sites: implications for the workplace. Business Communication Quarterly, (72)1, 105110.

Aharony, N. (2008, June). The use of wiki in an academic course: A qualitative investigation. Proceedings of the Informing Science \& IT Education Conference (InSITE) 2008. Retrieved March 1, 2010 from http://proceedings.informingscience.org/InSITE2008/InSITE08p147-153Aharony456.pdf

Alleycode. (n.d.). Retrieved from http//www.alleycode.com/

Armstrong, L., Berry, M., \& Lamshed, R. (2007). Blogs as electronic learning journals. Retrieved March 1, 2010 from http://www.usq.edu.au/electpub/e-jist/docs/Vol7_No1/CurrentPractice/Blogs.htm

AtSpace. (n.d.) Retrieved from http://www.atspace.com

Best of Blog. (n.d.) Retrieved from http://www.bestofblog.com/

Best of the Web Blogs. (n.d.) Retrieved from http://blogs.botw.org/

Blog Catalog. (n.d.) Retrieved from http://www.blogcatalog.com/

Blog Pulse. (n.d.) Retrieved from http://www.blogpulse.com/

Blogger. (n.d.) Retrieved from http://www.blogger.com

Bloglines. (n.d.) Retrieved from http://www.bloglines.com/

Blogscope. (n.d.) Retrieved from http://www.blogscope.net/

BYET Internet Services. (n.d.) Retrieved from www.byethost.com

Classroom 2.0. (n.d.) Retrieved from http://www.classroom20.com/

Commentpress. (n.d.) Retrieved from http://www.futureofthebook.org/commentpress/

Cummings, R. E. \& Barton, M. (2008). Wiki writing: Collaborative learning in the college classroom. Ann Arbor, MI: University of Michigan Press. Retrieved March 1, 2010 from http://books.google.com/books?id=U JosCxgBgC\&printsec $=$ frontcover\&dq $=$ matthew + barton + wikis \&source $=$ bl\&ots $=36 \mathrm{ECEg} 315 \mathrm{o} \&$ sig $=\mathrm{rQpR}$ fJYfz3J66w2xg2GnVvg3DYI\&hl=en\&ei=wQ2MS6azFcXJlAfhveGvDQ\&sa=X\&oi=book result\&ct= result\&resnum $=7 \& v e d=0 \mathrm{CB} 8 Q 6 \mathrm{AEwBg} \# \mathrm{v}=$ onepage $\& \mathrm{q}=$ matthew $\% 20 \mathrm{barton} \% 20$ wikis $\& \mathrm{f}=$ false

Facebook. (n.d.) Retrieved from htttp://www.facebook.com 
FreeLayouts. (n.d.) Retrieved from http://www.freelayouts.com/

Free Web Hosting. (n.d.) Retrieved from http://www.free-webhosts.com/reviews/

Google's Blog Search. (n.d.) Retrieved from http://blogsearch.google.com/

Kirk, D. J. \& Johnson, T. L. (2009, Winter). The use of blogs as a knowledge management tool. Academic Exchange Quarterly, (13)4, 50-55.

Komodo Edit. (n.d.) Retrieved from http://www.activestate.com/komodo_edit/

Lee, M. J. W., Miller, C., \& Newnham, L. (2008). RSS and content syndication in higher education: subscribing to a new model of teaching and learning. Educational Media International, (45)4, 311-322.

Luehmann, A. \& MacBride, R. (2009). Classroom blogging in the service of student-centered pedagogy: Two high school teachers' use of blogs. THEN: Technology, Humanities, Education, \& Narrative, 6, $5-36$.

Lundin, R. (2008). Teaching with wikis: Toward a networked pedagogy. Computers and Composition, $25(4), 432-448$.

McLoughlin, C. \& Lee, M. J. W. (2007). Social software and participatory learning: Pedagogical choices with technology affordances in the Web 2.0 era. In ICT: Providing choices for learners and learning. Proceedings ascilite Singapore 2007. Retrieved March 1, 2010 from http://www.ascilite.org.au/conferences/singapore07/procs/mcloughlin.pdf

Mochahost. (n.d.) Retrieved from http://www.mochahost.com/

Ning. (n.d.) Retrieved from http://www.ning.com

Panckhurst, R. \& Marsh, D. (2009, December). eLEN2 $-2^{\text {nd }}$ generation eLearning exchange networks. Online Educa Berlin, France. Retrieved March 1, 2010 from http://hal.archives-ouvertes.fr/hal$\underline{00443012 \%}$.

PBworks. (n.d.) Retrieved from http://pbworks.com/

PBworks Educator Community. (n.d.) Retrieved from http://educators.pbworks.com/

RSS Readers. (n.d.) Retrieved from http://blogspace.com/rss/readers

Techorati. (n.d.) Retrieved from http://technorati.com/

TemplatesBOX. (n.d.) Retrieved from http://www.templatesbox.com

Vista Intermedia Corporation. (n.d.) Retrieved from http://www.vistainter.com/

Web Hosting Jury. (n.d.) Retrieved from http://www.webhostingjury.com/

WetPaint. (n.d.) Retrieved from http://www.wetpaint.com

Wikia. (n.d.) Retrieved from http://www.wikia.com/Wikia

Wikipedia. (n.d.) Retrieved from http://en.wikipedia.org/wiki/List_of blogs

Wordpress. (n.d.) Retrieved from http://wordpress.com/ 


\section{Annotated List of Website References}

\section{Alphabetical Order by Name}

\begin{tabular}{|c|c|c|c|}
\hline Name & Category & Charge? & URL \\
\hline 110MB & Web hosting service & Free option & www.110mb.com \\
\hline 2 Create a Website & Web site designs & Free option & $\begin{array}{l}\text { http//www.2createawebsi } \\
\text { te.com/ }\end{array}$ \\
\hline 50Webs & Web hosting service & Free option & $\underline{\text { www. }}$ 50webs.com \\
\hline $\begin{array}{l}\text { Affordable Multi- } \\
\text { media }\end{array}$ & Web hosting service & Low cost & http//www.afmu.com/ \\
\hline Alleycode & $\begin{array}{l}\text { HTML, XHTML, } \\
\text { CSS and PHP editor } \\
\text { for PCs }\end{array}$ & Free option & $\underline{\mathrm{http} / \mathrm{www} \text {.alleycode.com }}$ \\
\hline At Space & Web hosting service & Free option & $\underline{\text { www.atspace.com }}$ \\
\hline Best of Blog & blog search engine & Not applicable & $\frac{\mathrm{http} / / \mathrm{www} \cdot \text { bestofblog.co }}{\mathrm{m} /}$ \\
\hline $\begin{array}{l}\text { Best of the Web } \\
\text { Blogs }\end{array}$ & blog search engine & Not applicable & http//blogs.botw.org/ \\
\hline Blog Catalog & blog search engine & Not applicable & $\underline{\mathrm{http} / / \mathrm{www} \cdot \mathrm{blog} \text { catalog.co }}$ \\
\hline Blog Pulse & blog search engine & Not applicable & $\frac{\mathrm{http} / / \mathrm{www} \cdot \text { blogpulse.com }}{\underline{I}}$ \\
\hline Blogger & blog creator & Free option & http//www.blogger.com \\
\hline Bloglines & blog search engine & Not applicable & $\frac{\mathrm{http} / \text { www.bloglines.com }}{I}$ \\
\hline Blogscope & blog search engine & Not applicable & http//www.blogscope.net/ \\
\hline $\begin{array}{l}\text { BYET Internet Ser- } \\
\text { vices }\end{array}$ & Web hosting service & Free option & www.byethost.com \\
\hline Classroom 2.0 & $\begin{array}{l}\text { social network for } \\
\text { educators using any } \\
\text { Web } 2.0 \text { features }\end{array}$ & Not applicable & $\begin{array}{l}\text { http//www.classroom20.c } \\
\underline{\mathrm{om} /}\end{array}$ \\
\hline Commentpress & WordPress plugin & Not applicable & $\frac{\text { http//www.futureofthebo }}{\text { ok.org/commentpress/ }}$ \\
\hline Facebook & social network & Not applicable & $\underline{\mathrm{htttp} / / \mathrm{www} \cdot \text { facebook.co }}$ \\
\hline
\end{tabular}




\begin{tabular}{|c|c|c|c|}
\hline Name & Category & Charge? & URL \\
\hline FreeLayouts & $\begin{array}{l}\text { templates for } \\
\text { websites and blogs, } \\
\text { MySpace layouts }\end{array}$ & Free option & $\begin{array}{l}\text { http//www.freelayouts.c } \\
\text { om/ }\end{array}$ \\
\hline Free-Webhosts & $\begin{array}{l}\text { Web host reviews } \\
\text { and ratings }\end{array}$ & Not applicable & $\begin{array}{l}\text { http//www.free- } \\
\text { webhosts.com/reviews/ }\end{array}$ \\
\hline $\begin{array}{l}\text { Google's Blog } \\
\text { Search }\end{array}$ & blog search engine & Not applicable & $\frac{\mathrm{http} / / \text { blogsearch.google.c }}{\mathrm{om} /}$ \\
\hline Komodo Edit & $\begin{array}{l}\text { HTML / multi- } \\
\text { language editor for } \\
\text { Macs and PCs }\end{array}$ & Free option & $\begin{array}{l}\mathrm{http} / / \mathrm{www} \cdot \text { activestate.co } \\
\mathrm{m} / \text { komodo_edit/ }\end{array}$ \\
\hline Mochahost & Web hosting service & Low cost & $\frac{\mathrm{http} / / \mathrm{www} \cdot \text { mochahost.co }}{\underline{\mathrm{m} /}}$ \\
\hline Ning & $\begin{array}{l}\text { social network site } \\
\text { host }\end{array}$ & Free option & http//www.ning.com \\
\hline PBworks & wiki creator and host & Free option & http//pbworks.com/ \\
\hline $\begin{array}{l}\text { PBworks Educator } \\
\text { Community }\end{array}$ & $\begin{array}{l}\text { social network for } \\
\text { educators using } \\
\text { PBworks }\end{array}$ & Not applicable & $\begin{array}{l}\text { http//educators.pbworks.c } \\
\text { om/ }\end{array}$ \\
\hline RSS Readers & $\begin{array}{l}\text { RSS feed readers, } \\
\text { ranked }\end{array}$ & Not applicable & $\begin{array}{l}\text { http//blogspace.com } / \mathrm{rss} / \mathrm{r} \\
\underline{\text { eaders }}\end{array}$ \\
\hline Techorati & blog search engine & Not applicable & http//technorati.com/ \\
\hline TemplatesBOX & $\begin{array}{l}\text { templates for web- } \\
\text { sites }\end{array}$ & Free option & $\begin{array}{l}\text { http//www.templatesbox. } \\
\underline{\text { com }}\end{array}$ \\
\hline $\begin{array}{l}\text { Vista Intermedia } \\
\text { Corporation }\end{array}$ & $\begin{array}{l}\text { Web host reviews } \\
\text { and ratings }\end{array}$ & Not applicable & $\underline{\mathrm{http} / \mathrm{www} \text {.vistainter.com }}$ \\
\hline Web Hosting Jury & $\begin{array}{l}\text { Web hosting reviews } \\
\text { and ratings }\end{array}$ & Not applicable & $\frac{\mathrm{http} / / \text { www.webhostingjur }}{\text { y.com/ }}$ \\
\hline WetPaint & $\begin{array}{l}\text { social network site } \\
\text { host }\end{array}$ & Free option & http//www.wetpaint.com \\
\hline Wikia & wiki creator and host & Free option & $\frac{\mathrm{http} / / \mathrm{www} \text {.wikia.com/Wi }}{\text { kia }}$ \\
\hline Wikipedia entry & $\begin{array}{l}\text { Blog list - notable } \\
\text { blogs }\end{array}$ & Not applicable & $\begin{array}{l}\text { http//en.wikipedia.org/wi } \\
\text { ki/List of blogs }\end{array}$ \\
\hline Wordpress & blog creator & Free option & http//wordpress.com/ \\
\hline
\end{tabular}




\section{Annotated List of Website References}

\section{Category Order}

\begin{tabular}{|c|c|c|c|}
\hline Category & Name & Charge? & URL \\
\hline \multirow[t]{2}{*}{ Blog creator } & Blogger & Free option & http//www.blogger.com \\
\hline & Wordpress & Free option & $\underline{\text { http//wordpress.com/ }}$ \\
\hline Blog list & Wikipedia entry & Not applicable & $\begin{array}{l}\text { http//en. wikipedia.org/wi } \\
\text { ki/List of blogs }\end{array}$ \\
\hline \multirow[t]{8}{*}{ Blog search engine } & Best of Blog & Not applicable & $\frac{\mathrm{http} / / \text { www.bestofblog.co }}{\underline{\mathrm{m} /}}$ \\
\hline & $\begin{array}{l}\text { Best of the Web } \\
\text { Blogs }\end{array}$ & Not applicable & http//blogs.botw.org/ \\
\hline & Blog Catalog & Not applicable & $\underline{\underline{\mathrm{http} / / \mathrm{www} \cdot \mathrm{blog} \text { catalog.co }}}$ \\
\hline & Blog Pulse & Not applicable & $\frac{\mathrm{http} / / \mathrm{www} \cdot \text { blogpulse.com }}{\underline{L}}$ \\
\hline & Bloglines & Not applicable & $\frac{\text { http//www.bloglines.com }}{L}$ \\
\hline & Blogscope & Not applicable & http//www.blogscope.net/ \\
\hline & $\begin{array}{l}\text { Google's Blog } \\
\text { Search }\end{array}$ & Not applicable & $\begin{array}{l}\text { http//blogsearch.google.c } \\
\underline{\mathrm{om} /}\end{array}$ \\
\hline & Techorati & Not applicable & http//technorati.com/ \\
\hline $\begin{array}{l}\text { HTML / multi- } \\
\text { language editor for } \\
\text { Macs and PCs }\end{array}$ & Komodo Edit & Free option & $\begin{array}{l}\underline{\mathrm{http} / / \mathrm{www} \cdot \text { activestate.co }} \\
\underline{\mathrm{m} / \text { komodo_edit/ }}\end{array}$ \\
\hline $\begin{array}{l}\text { HTML, XHTML, } \\
\text { CSS and PHP edi- } \\
\text { tor for PCs }\end{array}$ & Alleycode & Free option & $\underline{\mathrm{http} / / \mathrm{www} \cdot \text { alleycode.com }}$ \\
\hline $\begin{array}{l}\text { RSS feed readers, } \\
\text { ranked }\end{array}$ & RSS Readers & Not applicable & $\begin{array}{l}\text { http//blogspace.com/rss/r } \\
\underline{\text { eaders }}\end{array}$ \\
\hline Social network & Facebook & Not applicable & $\underline{\underline{\mathrm{htttp}} / / \mathrm{www} \cdot \text { facebook.co }}$ \\
\hline $\begin{array}{l}\text { Social network for } \\
\text { educators using any } \\
\text { Web } 2.0 \text { features }\end{array}$ & Classroom 2.0 & Not applicable & $\begin{array}{l}\underline{\mathrm{http} / / \mathrm{www} . c \text { lassroom20.c }} \\
\underline{\mathrm{om} /}\end{array}$ \\
\hline $\begin{array}{l}\text { Social network for } \\
\text { educators using } \\
\text { PBworks }\end{array}$ & $\begin{array}{l}\text { PBworks Educa- } \\
\text { tor Community }\end{array}$ & Not applicable & $\begin{array}{l}\text { http//educators.pbworks.c } \\
\mathrm{om} /\end{array}$ \\
\hline Social network site & Ning & Free option & http//www.ning.com \\
\hline
\end{tabular}




\begin{tabular}{|c|c|c|c|}
\hline Category & Name & Charge? & URL \\
\hline host & WetPaint & Free option & http//www.wetpaint.com \\
\hline $\begin{array}{l}\text { Templates for web- } \\
\text { sites }\end{array}$ & TemplatesBOX & Free option & $\begin{array}{l}\text { http//www.templatesbox. } \\
\underline{\text { com }}\end{array}$ \\
\hline $\begin{array}{l}\text { Templates for } \\
\text { websites and blogs, } \\
\text { MySpace layouts }\end{array}$ & FreeLayouts & Free option & $\begin{array}{l}\text { http//www.freelayouts.c } \\
\text { om/ }\end{array}$ \\
\hline \multirow[t]{3}{*}{$\begin{array}{l}\text { Web host reviews } \\
\text { and ratings }\end{array}$} & Free-Webhosts & Not applicable & $\begin{array}{l}\underline{\text { http//www.free- }} \\
\text { webhosts.com/reviews/ }\end{array}$ \\
\hline & $\begin{array}{l}\text { Vista Intermedia } \\
\text { Corporation }\end{array}$ & Not applicable & http//www.vistainter.com \\
\hline & $\begin{array}{l}\text { Web Hosting } \\
\text { Jury }\end{array}$ & Not applicable & $\begin{array}{l}\text { http//www.webhostingjur } \\
\text { y.com/ }\end{array}$ \\
\hline \multirow[t]{6}{*}{ Web hosting service } & $110 \mathrm{MB}$ & Free option & www.110mb.com \\
\hline & $50 \mathrm{Webs}$ & Free option & www.50webs.com \\
\hline & $\begin{array}{l}\text { Affordable Mul- } \\
\text { timedia }\end{array}$ & Low cost & http//www.afmu.com/ \\
\hline & At Space & Free option & www.atspace.com \\
\hline & $\begin{array}{l}\text { BYET Internet } \\
\text { Services }\end{array}$ & Free option & www.byethost.com \\
\hline & Mochahost & Low cost & $\underline{\mathrm{http} / / \text { www.mochahost.co }}$ \\
\hline Web site designs & $\begin{array}{l}2 \text { Create a Web- } \\
\text { site }\end{array}$ & Free option & $\begin{array}{l}\text { http//www.2createawebsi } \\
\text { te.com/ }\end{array}$ \\
\hline \multirow{2}{*}{$\begin{array}{l}\text { Wiki creator and } \\
\text { host }\end{array}$} & PBworks & Free option & $\underline{\text { http//pbworks.com/ }}$ \\
\hline & Wikia & Free option & $\begin{array}{l}\text { http//www.wikia.com/Wi } \\
\text { kia }\end{array}$ \\
\hline WordPress plugin & Commentpress & Not applicable & $\begin{array}{l}\text { http//www.futureofthebo } \\
\text { ok.org/commentpress/ }\end{array}$ \\
\hline
\end{tabular}




\section{Biographies}

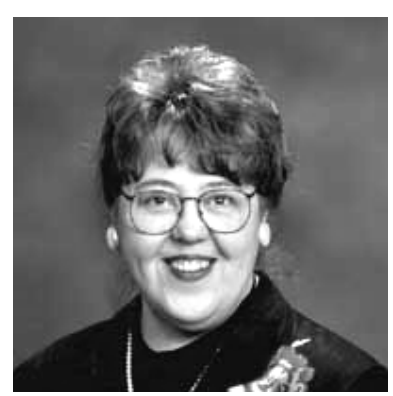

Linda V. Knight is Associate Dean of DePaul University's School of Computer Science, Telecommunications, and Information Systems. She is also Director of DePaul CTI's Center for the Strategic Application of Emerging Technologies (SAET), a CTI research group that explores leveraging new and emerging technology within organizations. She teaches and conducts research in the area of Information Technology strategy, development, and implementation. An Associate Editor of the Information Resources Management Journal, she also is a founding Editor of the Journal of IT Education, as well as a member of the Information Resources Management Association Executive Council. An entrepreneur and IT consultant, she has held industry positions in IT management and quality assurance management. In addition to a Ph.D. in computer science from DePaul University, she holds a B.A. in mathematics and an MBA, both from Dominican University.

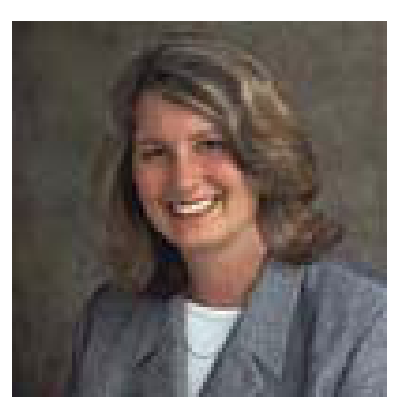

Theresa A. Steinbach began the Ph.D. program at DePaul CTI in January 2000, having received her M.S. in Information Systems in June 1999. She also holds an M.B.A. in Quantitative Economics and a B.A. in Mathematics from DePaul University. Her primary research interests are system development methodology and project management. Prior to teaching full-time for DePaul CTI, Terry owned her own consulting firm that specialized in maximizing technology for business growth and profits. Her client base included representatives from the banking and nursing home industries, accounting firms, mortgage bankers, park districts and other municipal entities, as well as small and mid-size retail businesses. 